\title{
Application of Project-Driven Teaching in College English Class
}

\author{
https://doi.org/10.3991/ijet.v16i21.26869
}

\author{
Shuting Cao, Hui Li $\left.{ }^{(}\right)$, Zhihao Wu, Haiyuan Liu, Miaomiao Yang \\ Cangzhou Normal University, Cangzhou, China \\ czszlhe126.com
}

\begin{abstract}
Project-driven teaching is a student-oriented teaching strategy to cultivate the autonomous learning ability of students. This paper tries to effectively apply project-driven teaching in college English class through a comparative experiment. The experimental results show that project-driven teaching greatly enhanced the satisfaction and learning effect of classroom English teaching. Throughout the teaching process, teachers are responsible for project design, project proposal, and dynamic monitoring of teaching effect; the students are responsible for accepting and completing the projects. Teachers work with the students to evaluate the completion of the projects and give feedback. The application of project-driven teaching in English class makes the classroom atmosphere more active, boosts the participation enthusiasm of students, and increases the attentiveness of students in English classroom. The research results provide theoretical evidence for English education reform.
\end{abstract}

Keywords-project-driven teaching, autonomous learning, English class, satisfaction, learning effect

\section{$1 \quad$ Introduction}

As mutual exchanges between countries around the global are becoming increasingly frequent these days, English proficiency has turned into an indispensable ability in modern society, thus the teaching of English language has received more attention from parents and schools $[1,2]$. Project-driven teaching means to set certain project tasks during the teaching activities and enable students to acquire language knowledge in the process of project completion [3,4]. This teaching method takes specific projects as learning motivation, takes the project completion process as the learning process, and uses project results to reflect the teaching results $[5,6]$. In addition, by carefully designing the teaching tasks, project-driven teaching constructs real scenes to carry out multi-dimensional interactive teaching activities [7].

Project-driven teaching manifests the student-centered and people-oriented educational philosophy, it designs different task-based activities for students of different levels $[8,9]$, closely connects with students' actual cognition levels and personal life experience, thereby better showing the humanistic spirit $[10,11]$. Project-driven teaching emphasizes the teaching theories of "using language to do things" and 
"learning by doing", and has been gradually introduced into English teaching in China $[12,13]$. In project-driven teaching, the English language is an organic whole which cannot be separated simply, students must understand, use, and master it through their own efforts of learning and analysis $[14,15]$. Compared with traditional teaching methods, project-driven teaching requires learners to participate, perceive and experience more in the project process; moreover, the interaction, communication, and cooperation among teachers and learners are also regarded as primary learning methods $[16,17]$.

Purposeful, cooperative, subjective, communicative, and realistic are the major characteristics of project-driven teaching [18]. In project-driven teaching, knowledge is constructed based on the learner's existing experience, psychological structure, and beliefs $[19,20]$; the teaching is conducted under the guidance of teachers, learners dominate the learning, and teachers act as guides [21]; leaners are the subjects of learning information processing and sense-making, not the passive receivers of knowledge indoctrination $[22,23]$. English education in schools is a process for students to learn and practice English, master English knowledge and skills, and improve actual language use ability [24]. This paper attempts to study the project-driven teaching method, and explores its application in English class, in the hopes of providing theoretical evidence for the reform of college English education.

\section{The research of English teaching in colleges}

\subsection{Status quo}

As a lingua franca, English is an important tool of international communication [25-27]. Since colleges vary greatly in terms of faculty level, student source, students' English foundation, and hardware facility, there're large differences in their English teaching situations $[28,29]$. Our research team conducted a questionnaire survey in 6 colleges in Hubei Province to investigate college students' interest in English and their learning habits. Figure 1 shows the statistics of students' English learning habits. Most of them are used to learning English via homework completion, few of them have the habits of reviewing homework, preparing before lessons, and practicing English speaking and listening, etc. Students' learning initiative is insufficient, they just learn English by completing homework using their after-class hours, few of them have the habit of using other channels to learn English, students generally pay less attention to English learning and they are not proactive in learning. Our survey revealed a few problems existing in current English teaching, as summarized in Figure 2 , including the aimless teaching management, the timeworn teaching facilities, the inability to meet teaching requirements, the stagnant textbook compilation, and the abstruse teaching content, etc. Many teachers are of low level and their teaching methods are outdated. Students only have a poor English foundation and they generally lack of self-confidence, manifesting as weak English basis, bad English learning habits, insufficient learning motivation, and low self-evaluation. 


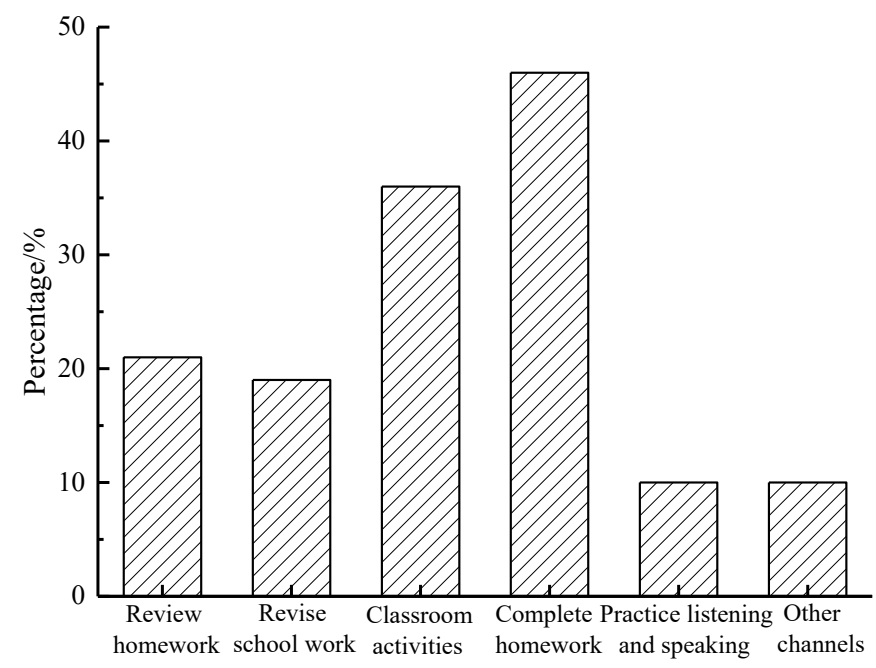

Fig. 1. Statistics of students' English learning habits

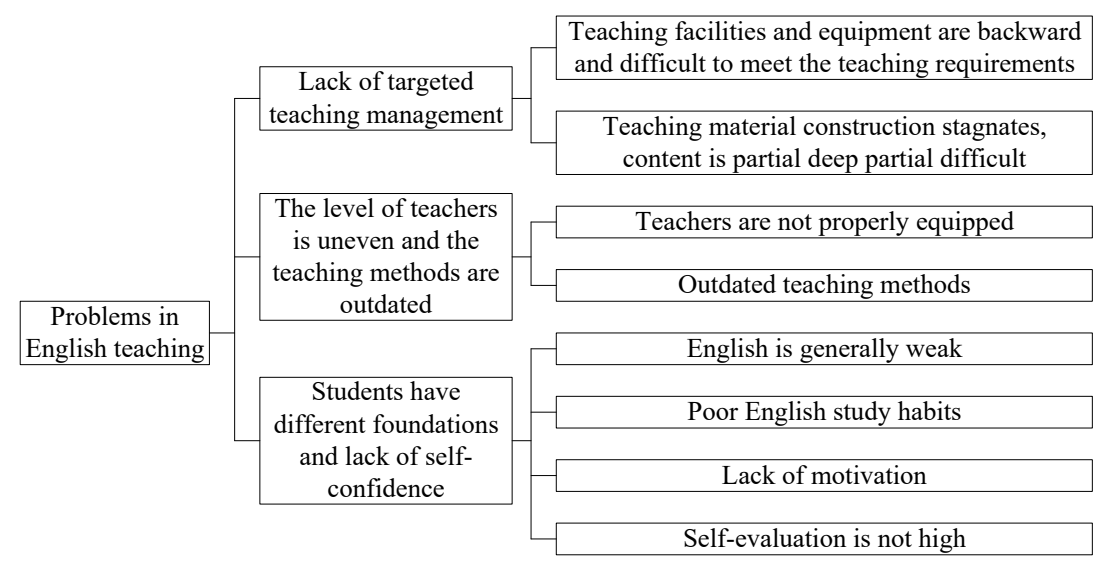

Fig. 2. Problems in current English teaching

\subsection{Advantages of project-driven teaching}

English teaching is the same as mother tongue language teaching, students understand, memorize, and apply the language through visual and auditory stimuli [30-31]. Project-driven teaching enables students to have a perceptual understanding of the knowledge they learnt through situational teaching, attracting their attention, and thus triggering their interest in English learning [32]. Figure 3 lists the advantages of project-driven teaching in English class. First, it can cultivate students' interest in learning English, in the entire English teaching process, teachers become guides, students take their initiative in analyzing and solving the problems, naturally, their learning interesting will increase. Second, it can motivate students to learn English, in the 
process of using English to complete the projects, students are always in an active learning state, the method gives students the opportunity to experience success in learning and improvement in performance, which can enhance their self-confidence and learning motivation. Third, it can strengthen students' ability of autonomous learning, project-driven teaching is a participation-style teaching method, in the entire learning process, students are the subjects of learning, they take the initiative and actively participate in learning through multiple methods such as self-experience, discussion and exchange, team work, and inquiry learning, etc. Fourth, it can promote communication between teachers and students, in the project participation process, teachers and students work together to help students who have difficulties in completing the projects, they communicate interactively throughout the entire process. Fifth, it can foster students' all-round development, their ability of raising and solving problems could be cultivated via coping with different projects, moreover, in this process, their ability of independent learning, inquiry learning, innovation, and communication could be cultivated as well.

\begin{tabular}{|c|c|}
\hline $\begin{array}{c}\text { Develop students' interest in learning } \\
\text { English }\end{array}$ \\
\hline $\begin{array}{c}\text { The advantages of } \\
\text { project-driven Approach } \\
\text { in English teaching }\end{array}$ & $\begin{array}{c}\text { Provide motivation for students to learn } \\
\text { English }\end{array}$ \\
\hline & $\begin{array}{c}\text { Improve students' independent English } \\
\text { learning ability }\end{array}$ \\
\hline To promote the all-round development \\
of students
\end{tabular}

Fig. 3. Advantages of project-driven teaching in English class

\section{Application of project-driven teaching in English class}

\subsection{The practice of project-driven teaching in English class}

English teaching is a dynamic process, learners could only develop their cognition ability and language skills through active experience and participation [33]. Figure 4 shows the design principles of project-driven teaching, including the principle of authentic language scenes, the principle of form and function, the principle of stepshaped tasks, the principle of interrelated language and affairs, and the principle of stratified teaching and group cooperation. In project-driven teaching, the form and meaning of the language are closely integrated [34, 35]. Figure 5 is a structure diagram of project-driven teaching. Teachers design projects, propose projects, and conduct dynamic monitoring on teaching throughout the whole process; students accept 
and complete the projects, then teachers and students jointly evaluate the project completion situation and give feedback. In order to explore the application of projectdriven teaching in English class, we conducted a teaching experiment on students in a college in Hubei province, Table 1 gives the basic information of the experimental group and the control group. The project-driven teaching method was adopted in the English class of the experimental group.

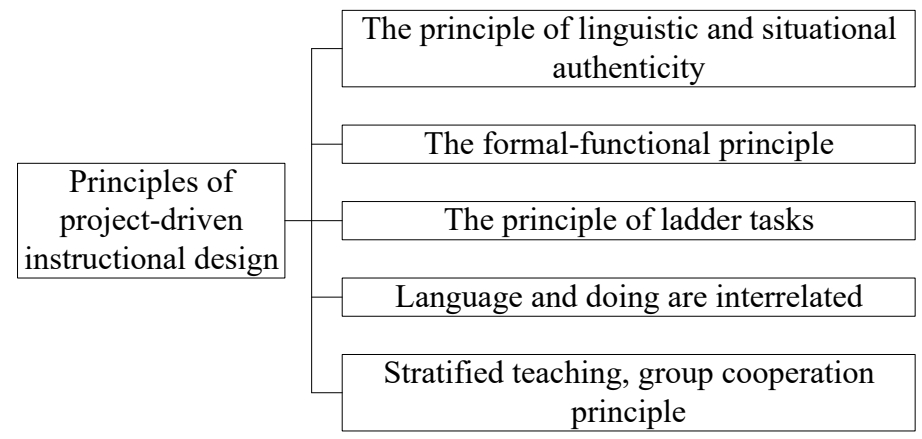

Fig. 4. Design principles of project-driven teaching

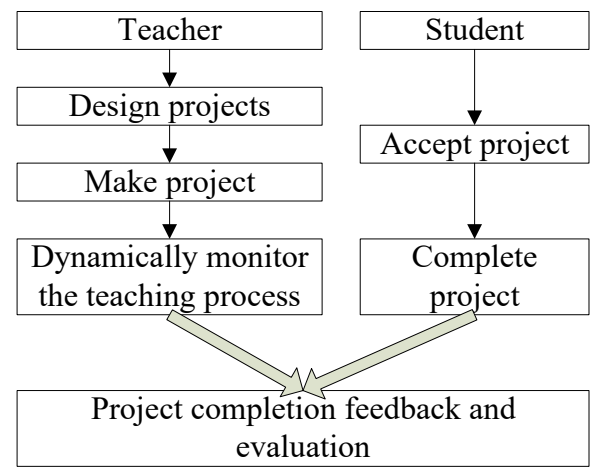

Fig. 5. Structure of the project-driven teaching

Table 1. Basic information of experimental group and control group

\begin{tabular}{|l|c|c|c|}
\hline \multicolumn{1}{|c|}{ Group } & Number & Male & Female \\
\hline Experimental group & 60 & 27 & 33 \\
\hline Control group & 59 & 25 & 34 \\
\hline
\end{tabular}

\subsection{The application effect of project-driven teaching in English class}

In English teaching, the designed projects must be authentic in terms of pragmatics, context, and semantics, also the projects should be practical, interesting, and operable in teaching. During teaching activities, teachers need to reasonably group students according to their learning attitude, ability level, personality, hobbies, and spe- 
cialties, and then assign the roles of each student in the project. Figure 6 and Figure 7 are respectively the English test scores of the two groups before and after the experiment, as can be seen from the figures, before the experiment, there's no obvious difference in the vocabulary, grammar, reading, writing, listening, and speaking scores between the two groups. After the project-driven teaching method had been applied, the English test scores of the experimental group were all higher than those of the control group. Figure 8 shows the statistics of the approval of the effect of projectdriven teaching, as can be seen from the figure, all dimensions of the approval of the effect of project-driven teaching are above $80 \%$, the dimensions of satisfaction with teaching method, interest in teaching mode, and improving the comprehensive English ability all gained a high approval rate. Figure 9 is a comparison of the grades of completed works of the two groups. Figure 9(a) is the grades of the completed works of the experimental group, the excellent rate is $18.33 \%$, the good rate is $53.34 \%$, and the average rate is $28.33 \%$. Figure 9 (b) is the grades of the completed works of the control group, the excellent rate is $1.69 \%$, the good rate is $27.12 \%$, the average rate is $66.11 \%$, and the failed rate is $5.08 \%$. These results indicate that after the application of the project-driven teaching method, the excellent rate and good rate of the completed English works had been significantly improved.

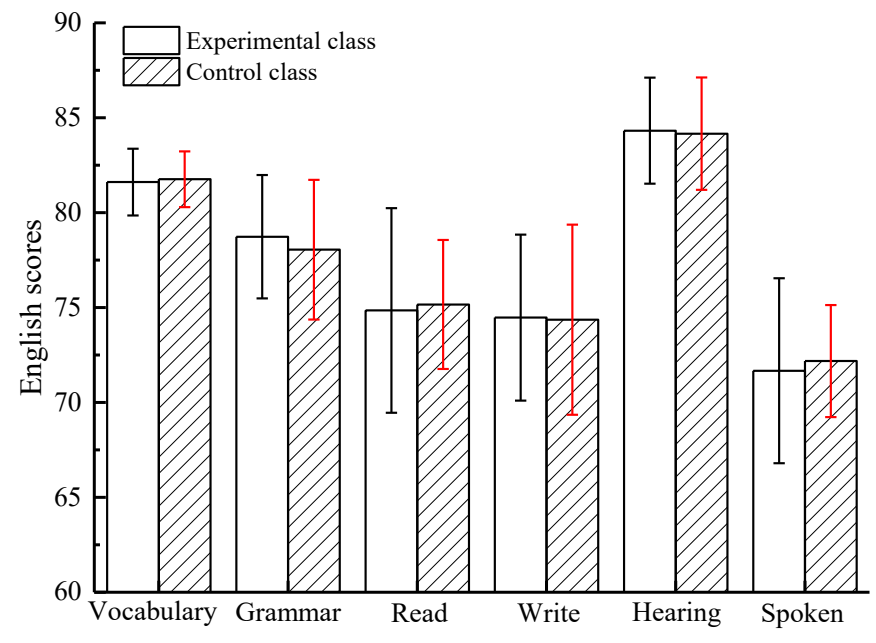

Fig. 6. English test scores before the experiment 


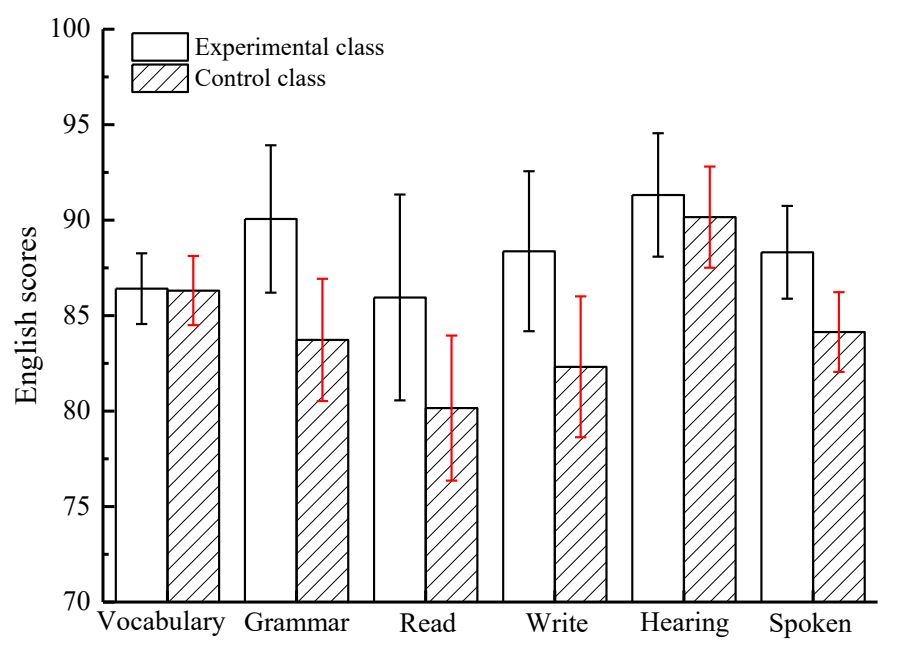

Fig. 7. English test scores after the experiment

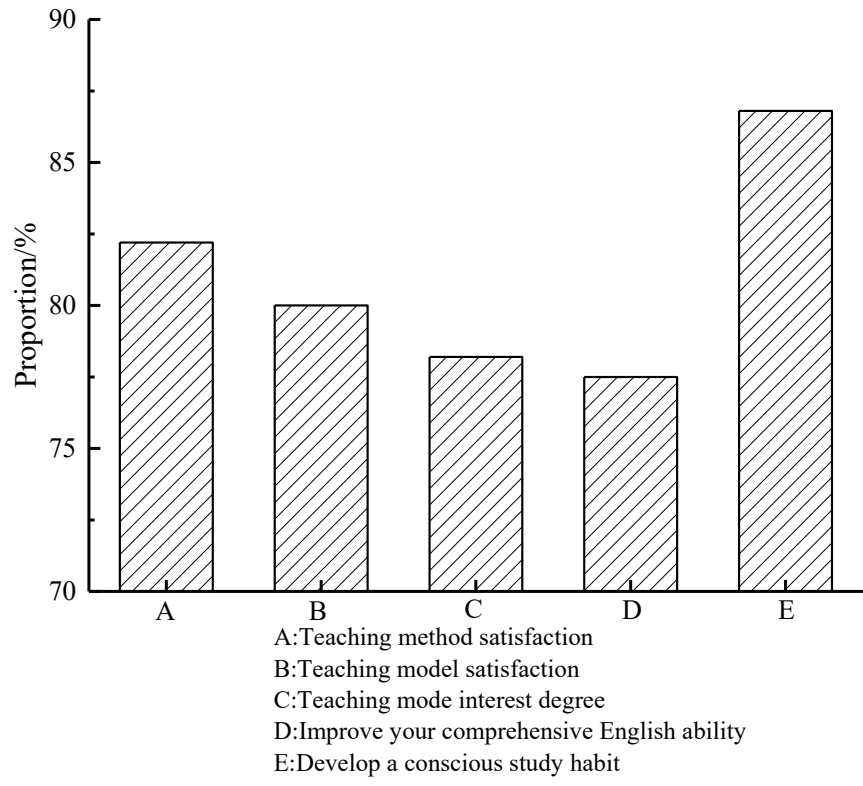

Fig. 8. Statistics of the approval of the effect of project-driven teaching 


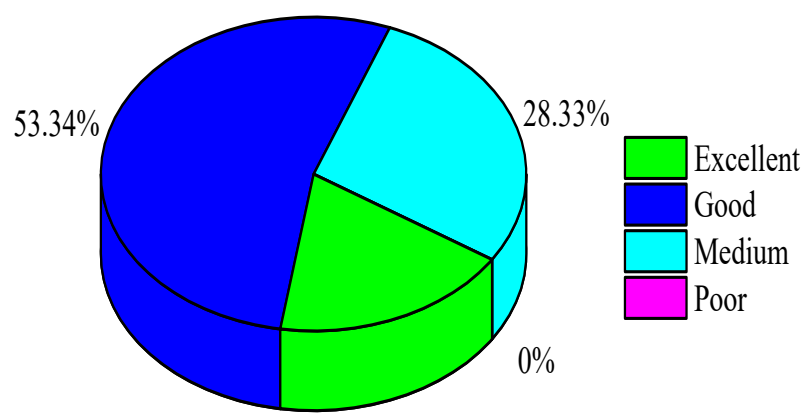

$18.33 \%$

a) Experimental group

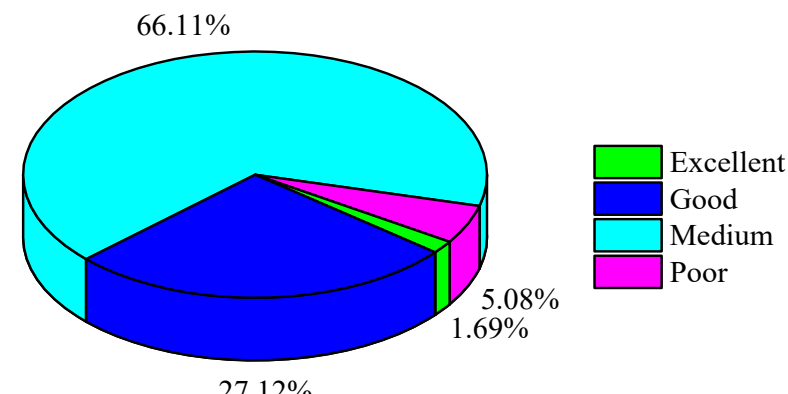

b) Control group

Fig. 9. Grades of completed works of the two groups

\section{Evaluation of the implementation process of project-driven teaching}

Teaching methods can directly affect the learning initiative and learning interest of students and the organization and management of the classroom, which will ultimately affect the teaching results and students' performance. From the English test scores and classroom satisfaction evaluation shown in Section 3.2, we can see that the project-driven teaching method had indeed improved students' course performance and their satisfaction with classroom teaching. Figure 10 shows the evaluation of the English class taught by the project-driven teaching method. The overall comment is that the classroom atmosphere is active and students generally have a high degree of enthusiasm for participation. Survey results tell us that $61.9 \%$ of the students think that the classroom atmosphere is active and their learning initiative is high; $23.81 \%$ of the students think that the classroom atmosphere is average and they hold an indifferent attitude towards the tasks; $9.52 \%$ of the students think that the classroom atmosphere 
is not good and they prefer to do their own things in class; $4.76 \%$ of the students think that the classroom discipline is poor and they cannot complete their projects. Figure 11 shows the measures taken by students when encountering difficulties during project completion process, more students choose to turn to teachers and other group members, and $24.75 \%$ of them solve the issues by after-class self-study. Figure 12 shows the influence of project-driven teaching on students' attentiveness in class. $27.18 \%$ of the students think that their attention is much more concentrated in class when the project-driven teaching method is adopted, $53.4 \%$ of the students think that their attention is more concentrated, overall speaking, more than $80 \%$ of the students believe the project-driven teaching method had improved their learning concentration in English class.

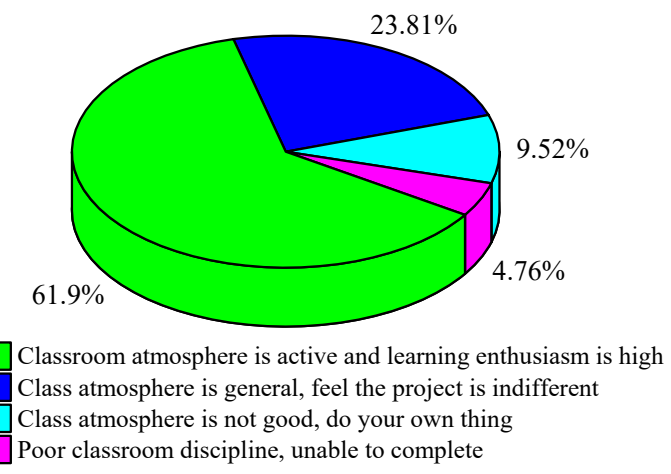

Fig. 10.Evaluation of English class taught by the project-driven teaching method

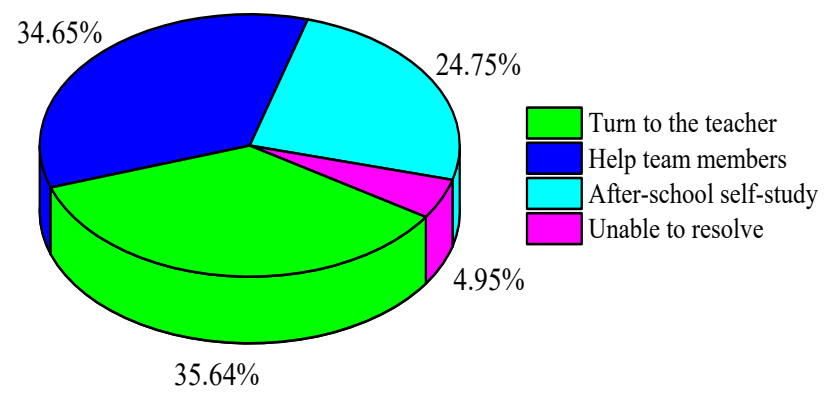

Fig. 11.Measures taken by students when encountering difficulties during project completion 


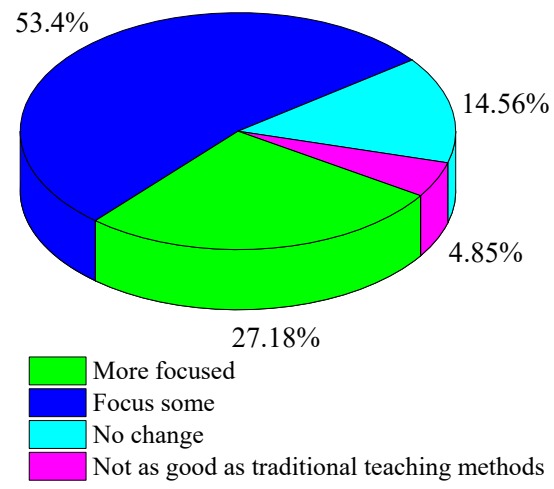

Fig. 12. The influence of project-driven teaching on students' attentiveness in class

\section{Countermeasures to promote project-driven teaching}

Clear objectives during the project completion process are conducive to triggering students' learning motivation, they enable students to see achievements and experience success more easily, which can greatly stimulate their learning enthusiasm. In order to promote project-driven teaching in English education, this paper proposes several countermeasures, as listed in Figure 13. The first is the construction and effective application of the teaching environment, modern multimedia technologies could be adopted scientifically in teaching, and simulation training rooms and virtual network teaching environment could be created. Second, with social and market demands as the orientation, the teaching content and English exercise content should be enriched and updated constantly, and the English teaching scenes should be close to our daily life. Third, in terms of project design, the designed projects should be effective, practical, and interesting; also, the teaching plans should be well designed for the project-driven teaching. Fourth, we should cultivate teachers to have both theoretical and practical teaching qualities, based on the market-oriented talent demands, teachers should continuously improve their knowledge and professional skills. Fifth, we should enhance English teachers' ability to monitor the teaching process and teaching quality. Sixth, a harmonious relationship should be created between teachers and students, such harmonious teacher-student relationship is usually established through the interaction between teachers and students, in the project implementation process, teachers should fully respect students' role as learners, and establish a good relationship with students by offering effective guidance. 


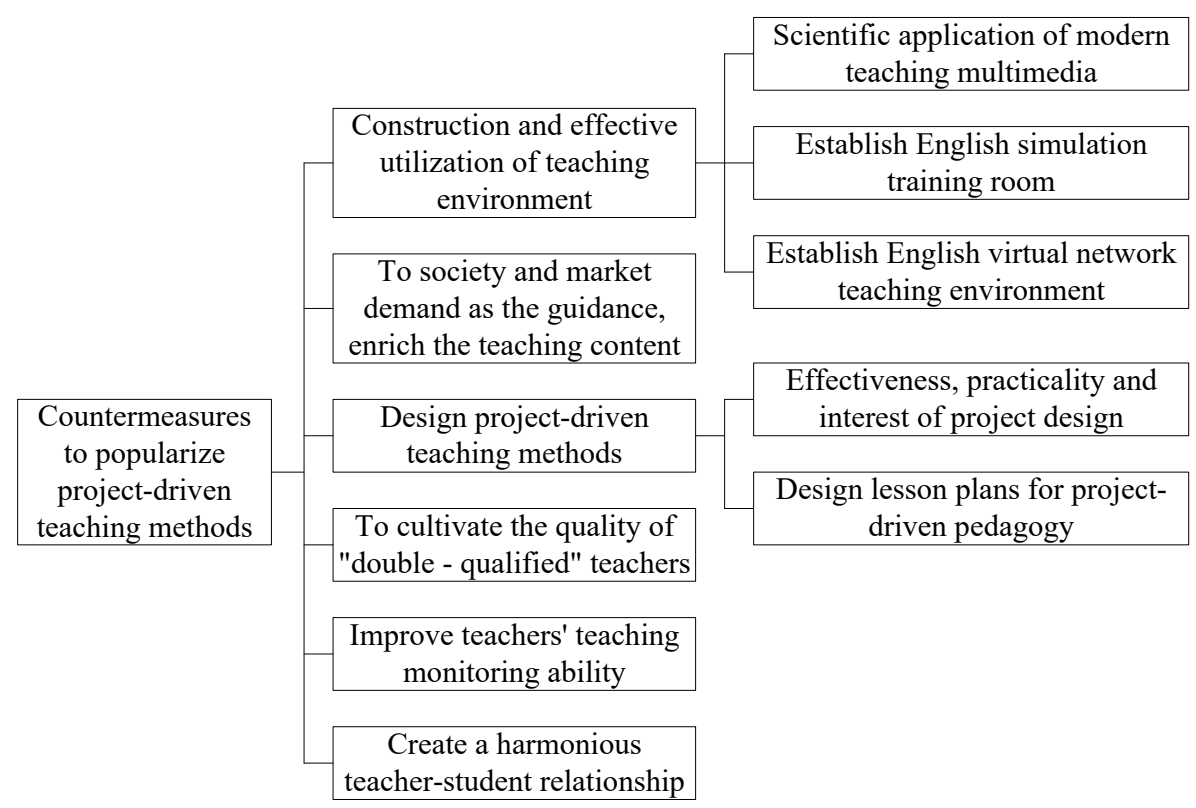

Fig. 13.Countermeasures to promote project-driven teaching

\section{Conclusions}

This paper studied the project-driven teaching, explored its application in college English class, and proposed a few countermeasures for promoting the project-driven teaching method, the specific conclusions are:

1. Project-driven teaching can cultivate students' interest in learning, motivate them to learn English, strengthen their ability of autonomous learning, promote communication between teachers and students, and foster students' all-round development.

2. After applying project-driven teaching, the vocabulary, grammar, reading, writing, listening, and speaking scores of the experimental group were all higher than those of the control group, and the excellent rate and good rate of the completed English works had been significantly improved.

3. After applying project-driven teaching, the overall comment is that the classroom atmosphere is active, students generally have a high degree of enthusiasm for participation, and the learning concentration of students in English class has been greatly improved.

\section{$7 \quad$ References}

[1] Liu, D. (2020). Application of computer network technology in the research of college English teaching strategy. Journal of Physics Conference Series, 1648: 022038. https://doi.org/10.1088/1742-6596/1648/2/022038 
[2] Thu, N.T.H. (2020). Communication Skills and Reflection Practice in Smart English Teaching and Learning Environment: A Case Study, International Journal of Emerging Technologies in Learning, 15(17), 221-237. https://doi.org/10.3991/ijet.v15i17.15235

[3] Sun, C. (2020). Research on the application of SPOC online and offline hybrid teaching mode in college English curriculum. IOP Conference Series Materials Science and Engineering, 750: 012170. https://doi.org/10.1088/1757-899x/750/1/012170

[4] Su, F. (2019). Application research of college English teaching resources based on knowledge base management platform. Journal of Physics: Conference Series, 1345(5): 052072. https://doi.org/10.1088/1742-6596/1345/5/052072

[5] Chen, H. (2020). Exploration and research of information technology in college English teaching. Journal of Physics Conference Series, 1648: 022021. https://doi.org/10.1088/ $\underline{1742-6596 / 1648 / 2 / 022021}$

[6] Wang, Y. (2021). Application of big data technology in English teaching innovation. Journal of Physics Conference Series, 1744(3): 032007. https://doi.org/10.1088/1742$\underline{6596 / 1744 / 3 / 032007}$

[7] Deng, Y. (2021). Research on the application analysis of four-dimensional teaching method in higher vocational English teaching based on big data analysis. Journal of Physics Conference Series, 1744(3): 032059. https://doi.org/10.1088/1742-6596/ $\underline{1744 / 3 / 032059}$

[8] Li, R. (2013). Key technology on construction of college English multimedia teaching website. Applied Mechanics \& Materials, 433-435: 2480-2483. https://doi.org/10.4028/ www.scientific.net/amm.433-435.2480

[9] Zhang, X., Wang, J. (2018). Application research of computer-aided teaching based on network in college English teaching reform. Kuram ve Uygulamada Egitim Bilimleri, 18(5): 1765-1774. https://doi.org/10.12738/estp.2018.5.076

[10] Qian, Y. (2018). Application research of e-learning network teaching platform in college English reading teaching. Educational Sciences: Theory and Practice, 18(5): 1819-1827. https://doi.org/10.12738/estp.2018.5.082

[11] Wang, X. (2016). Discussion on application of multimedia teaching in college English vocabulary teaching. Open Journal of Modern Linguistics, 6(3): 177-181. https://doi.org/10.4236/ojml.2016.63018

[12] Zhou, D. (2015). An empirical study on the application of process approach in NonEnglish majors' writing. English Language Teaching, 8(3). https://doi.org/10.5539/elt. $\underline{\mathrm{v} 8 \mathrm{n} 3 \mathrm{p} 89}$

[13] Lin, L.C., Yu, W.Y. (2015). A think-aloud study of strategy use by EFL college readers reading Chinese and English texts. Journal of Research in Reading, 38(3): 286-306. https://doi.org/10.1111/1467-9817.12012

[14] Zhao, S. (2017). Application research on CBI teaching philosophy and models in college English teaching. Journal of Mudanjiang College of Education, 5: 46-48. https://doi.org/ 10.3969/j.issn.1009-2323.2017.05.016

[15] Zhao, X. (2017). The application of computer technology in Mongolian college English teaching. International Journal of Emerging Technologies in Learning, 12(2): 52-65. https://doi.org/10.3991/ijet.v12i02.6044

[16] Meng, J. (2017). An empirical study on the application of cooperative learning to comprehensive English classes in a Chinese independent college. English Language Teaching, 10(2): 94-99. https://doi.org/10.5539/elt.v10n2p94

[17] Li, X.P. (2017). Snapshot, bold show - application of student's micro-video in spoken English teaching in Chinese higher vocational colleges. Journal of Linguistics and Literature, 1(1): 21-28. 
[18] Cao, L. (2012). A feasibility study of task-based teaching of college English writing in Chinese EFL context. English Language Teaching, 5(10): 80-91. https://doi.org/10. $\underline{5539 / \mathrm{elt} . v 5 \mathrm{n} 10 \mathrm{p} 80}$

[19] Zhi, L., Hong, Z. (2012). The construction of practical teaching mode of English for golf major. Advances in Intelligent and Soft Computing. https://doi.org/10.1007/978-3-64227866-2_116

[20] Sun, Y. (2015). A research on English teaching quality in ethnic colleges and the application of BP neural network. Information Technology and Career Education, 121128. https://doi.org/10.1201/b18416-18

[21] Qian, W. (2015). Study on the new model of college English teaching under the setting of multimodality. Universal Journal of Educational Research, 3(8): 473-477. https://doi.org/ $10.13189 /$ ujer.2015.030801

[22] Tan, X. (2015). A research on the application of cooperative learning in rural middle school English teaching. Journal of Language Teaching and Research, 6(4): 847-854. https://doi.org/10.17507/jltr.0604.19

[23] Tan, W.Y. (2015). Application of network teaching based on internet in English teaching. International Journal of Simulation: Systems, Science and Technology, 16(2A): 16(1-5). https://doi.org/10.5013/IJSSST.a.16.2a.16

[24] Yue, Z. (2015). The application study of the interpretive theory in the college English course - the case study of Qingdao university of science and technology. Journal of Language Teaching and Research, 6(5): 1140-1144. https://doi.org/10.17507/jltr.0605.29

[25] Dong, J., Yu, H.W. (2020). Particle swarm optimization neural network for research on artificial intelligence college English classroom teaching framework. Journal of Intelligent and Fuzzy Systems, 40(2): 3655-3667. https://doi.org/10.3233/jifs-189400

[26] Li, C., Gu, Y. (2020). The application of case teaching method in computer English teaching under OBE mode__ taking college English blending teaching of Hetao college as an example. E3S Web of Conferences, 218(7): 04003. https://doi.org/10.1051/e3sconf/ $\underline{202021804003}$

[27] Cui, J. (2020). Application of deep learning and target visual detection in English vocabulary online teaching. Journal of Intelligent and Fuzzy Systems, 39(4): 5535-5545. https://doi.org/10.3233/jifs-189035

[28] Hong-Juan, P.U. (2019). Application of mind mapping in college English teaching. Education Teaching Forum, 124: 314-315. https://doi.org/10.1111/bcpt.13217

[29] Huang, Y., Wang, Y., Ye, F. (2019). A study of the application of word cloud visualization in college English teaching. International Journal of Information and Education Technology, 9(2): 119-122. https://doi.org/10.18178/ijiet.2019.9.2.1185

[30] Yuan, Z., Lu, Z. (2019). College English teaching status and individualized teaching design in the context of mobile learning. International Journal of Emerging Technologies in Learning (iJET), 14(12): 85-96. https://doi.org/10.3991/ijet.v14i12.10704

[31] Zhang, H. (2019). A flipped classroom-based education system for college English teaching. International Journal of Emerging Technologies in Learning, 14(16): 120-129. https://doi.org/10.3991/ijet.v14i16.11152

[32] He, X. (2015). An action research on improving non-English majors' English writing by basic sentence pattern translation drills. English Language Teaching, 9(1): 142. https://doi.org/10.5539/elt.v9n1p142

[33] Chien, C. (2016). The teaching resources center: the application of practical teaching methods for lifelong learning. Universal Journal of Educational Research, 4(12A): 180185. https://doi.org/10.13189/ujer.2016.041323 
[34] Tan, X., Wang, C., Peng, L. (2013). Application of cooperative principle in college English listening comprehension. English Linguistics Research, 2(2): 27. https://doi.org/ $10.5430 /$ elr.v2n $2 \mathrm{p} 27$

[35] Zhang, X., Hung, S. C. (2013). A case study of exploring viability of task-based instruction on college English teaching in big-sized class. Journal of Language Teaching \& Research, 4(4): 693-699. https://doi.org/10.4304/jltr.4.4.693-699

\section{Authors}

Shuting Cao, female, lecturer, was born on October 10,1988, with a Master's degree, majors in English Translation. She is currently working in Cangzhou Normal University, which is located in Hebei Province, China. She has been teaching English courses for 5 years, including College English, Commercial English and CAT. She has published several papers on English teaching and translation, led over 10 projects at different levels (Email: caoshuting1988@163.com).

Hui Li, female, associate professor, was born on July 21, 1975, in Cangzhou City, Hebei Province, China with a Master's degree, majors in English Linguistics and Literature. She is currently working as an English teacher at Cangzhou Normal University in Cangzhou, China. She has been teaching English-courses for 24 years, including Intensive English, English Pedagogy, Journalism English, English Public Speaking, and oral English. She has published several papers on English teaching and led several provincial research projects and an important participant in several English MOOC courses circulating in China. She has been a visiting scholar to University of International Business and Economics for one year (2021).

Zhihao Wu, male, lecturer, was born on August 6, 1986 in Cangzhou City, Hebei Province, China. He received his B.A degree in English Literature from Hebei University of Economics and Business in 2009 and M.A degree majoring in Foreign Linguistics and Applied Linguistics from Guangxi University in 2012. He has been teaching English for 8 years, including College English, The Latest Survey of the United Kingdom and the United States, Applied Linguistics. He has published several papers on second language acquisition and inter-cultural communication (Email: ei20201202@163.com).

Haiyuan Liu, female, lecturer, was born on November 11, 1985, with a Master's degree, majors in Foreign Linguistics and Applied Linguistics. She is currently working as an English teacher at Cangzhou Normal University in Cangzhou, China. She has been teaching English-courses for 8 years, including College English, Essential English and linguistics. She has published several papers on English teaching and led several projects (Email: pennykitty@163.com).

Miaomiao Yang, female, college student, was born on February 25, 2002, majors in Business English. Courses she takes include Senior English, Economics, English Reading, Business English Translation, Oral English, etc. She has been a winner in several national college business contests and has passed CET-6 with an excellent performance (Email: ymm911225@163.com).

Article submitted 2021-09-07. Resubmitted 2021-10-12. Final acceptance 2021-10-13. Final version published as submitted by the authors. 